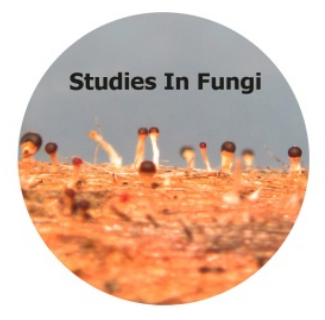

Studies in Fungi 4(1): 185-191 (2019) www.studiesinfungi.org ISSN 2465-4973

Article

Doi 10.5943/sif/4/1/20

\title{
Notes on the genus Arrhenia (I): Arrhenia pontevedrana, sp. nov. and A. subglobisemen (Agaricales, Basidiomycota), from the northwest of the Iberian Peninsula
}

\section{Blanco-Dios JB}

Centro de Formación e Experimentación Agroforestal de Lourizán. Consellería do Medio Rural. Xunta de Galicia. P.O. Box 127. 36003 Pontevedra, Spain

Blanco-Dios JB 2019 - Notes on the genus Arrhenia (I): Arrhenia pontevedrana, sp. nov. and A. subglobisemen (Agaricales, Basidiomycota), from the northwest of the Iberian Peninsula. Studies in Fungi 4(1), 185-191, Doi 10.5943/sif/4/1/20

\begin{abstract}
Arrhenia pontevedrana is described as a new species to science from Galicia (NW of Iberian Peninsula) based on morphological characteristics. A detailed description of basidiomata and microstructures of this species and a comparison with its morphologically closely related taxa are given. Arrhenia subglobisemen is recorded for the first time from the Iberian Peninsula. The new combination Arrhenia kuhnerii is also proposed.
\end{abstract}

Key words - Biodiversity - Spain - Taxonomy - Tricholomataceae

\section{Introduction}

Arrhenia Fr. is a genus with a world-wide distribution but the majority of taxa are described from temperate regions. According to Index Fungorum (2019), this genus contains 63 taxa (62 species and 1 variety). The genus Arrhenia is comprised mainly of bryophilous species characterized by omphalinoid or pleurotoid habit, poorly-developed hymenophores with lamellate hymenium concolorous with pileus and stipe, irregular hymenophoral trama, presence of clamps or not, membranal to weakly incrusting pigment of pileipellis, lack of cystidia and non-amyloid spores (Redhead 1984, Redhead et al. 2002, Barrasa et al. 2003).

Recent phylogenetic analyses for agarics have been suggested solutions for systematic treatment of the core omphaloid genera in the Agaricales (Moncalvo et al. 2002, Redhead et al. 2002). Consequenly, omphalinoid, nonlichenized species previously included in Omphalina s.l. have been reevaluated and the concept for the bryophilous species of Arrhenia and Omphalina was emended. Thus, many of the species previously included in Omphalina s.l. with greyish, blackish, bluish or brown-grey pileus and stipe and concolorous hymenia were transferred to Arrhenia. Later, an enlarged range of colours for the species of Arrhenia, proposed by Barrasa et al. (2003), includes gray, gray-brown, dark gray, fuscous, pale gray, withish, almost white, white or yellow hues basidiomata. However, species with reddish brown, rusty, vinaceous brown or orangish brown pileus and stipe with non-concolorous hymenia were retained in Omphalina (Redhead et al. 2002). In this sense, the genus Arrhenia constitutes a monophyletic bryophilous group that includes: (a) forms with nutant, pleurotoid or cyphelloid basidiomata (Arrhenia s. str.) and (b) the more typical mesopodal lamellate omphalinoid forms with greyish basidiomata formerly treated under the genus. 
Omphalina and Phaeotellus (Norvell et al. 1994) but excluding those reddish-brown species related to O. pyxidata (Bull.: Fr.) Quél., the conserved lectotype of Omphalina (Moncalvo et al. 2000, 2002, Redhead et al. 2002). Micromorphological features, such as nonamyloid spores, subregular to irregular hymenophoral trama and pileipellis with incrusting pigment, are shared by all members of the genus Arrhenia (Barrasa \& Rico 2003).

During the study of the micological flora of the Pontevedra municipality, an unidentified species of Arrhenia Fr. was collected growing among mosses. An extensively reviewing of the European and extra-European species of this genus confirmed that no other published species matched the particular combination of characters exhibited by our collections. Due to its unique combination of macroscopic and microscopic characteristics, a new species for science is proposed in this contribution. Arrhenia subglobisemen Corriol has also been found during this study, a species unknown until now in the Iberian Peninsula.

\section{Materials \& Methods}

\section{Morphological analysis}

The specimens were collected, documented and preserved using standard methods. Morphological descriptions are based on the study of the fresh material. Microscopic observations were recorded on fresh and/or dried material with standard methods, using sections mounted in water (basidiospores) or in a solution of $1 \%$ Congo Red in water after a short pre-treatment in a $5 \%$ potassium hydroxide solution or in $\mathrm{NH}_{4} \mathrm{OH}$. Basidiospores measurements (length, width, Q (quotient length/width)) were taken for 30 basidiospores on spore-print. Extreme values have been noted between brackets when they represented no more than $10 \%$ of the measurements. Microscopic structures were drawn with help of a drawing tube. The collected and studied material has been deposited in the mycological herbarium LOU-Fungi (Centro de Investigación Forestal de Lourizán, Pontevedra, Spain).

\section{Results}

\section{Taxonomy}

Arrhenia pontevedrana Blanco-Dios, sp. nov.

Figs $1-2$

MycoBank number: MB 811429

Etymology - pontevedrana, from the municipality and province of Pontevedra (Galicia, Spain), in which it was collected.

Habitus pleurotoideus. Pileus 2.5-3.5 mm latus, ab ovoideus ad chordatus, tomentosus, margine gossypinus vel gossypino-pruinosus, albus, rubro-roseus vittatus. Lamellae distans, decurrens, furfuraceae, ab albae ad cremeae. Lamellulae praesentes. Stipes 1.5-2 mm longus, 0.75$1.5 \mathrm{~mm}$ latus, eccentricus vel lateralis, curvatus, subcylindraceus, albus, gossypinus. Caro tenuis, albida, inmutabile exposita. Odor et sapor haud notabilis. Sporae (5) 5.5-6.5 (7) × (2.8) 3-3.5 (4) $\mu \mathrm{m}, \mathrm{Q}=1.55-2, \mathrm{Qm}=1.75$, ab ellipsoidae ad oblongae, hyalinae, inamyloidae. Basidia 15-21.5 $\times$ 5-7.5 $\mu \mathrm{m}$, clavata, tetrasporigera, fibulata. Acies lamellarum homogenea. Queilocystidia et pleurocystidia desunt. Pileipellis ex hyphis cylindraceis cutem formantibus 2.5-9 $\mu \mathrm{m}$ latis, pigmentum ab ochreo-griseo ad brunneo, minute incrustatis. Fibulae praesentes. Inter muscus in Castanea, Eucalyptus et Picea nemoris crescens.

Basidiomata pleurotoid. Pileus 2.5-3.5 mm diam, hoof-shaped in side view, ovoid to chordate or fan-shaped in face view; surface dull, dry, tomentose, with margin cottony, cottony-pruinose, with pink-red bands (a day later those red colors are more accentuated) on white background. Lamellae distant, decurrent, entirely furfuraceous, white to cream, edge concolourous, even, obtuse; lamellulae present. Stipe $1.5-2 \times 0.75-1.5 \mathrm{~mm}$; attached eccentrically to nearly laterally from pileus to the substrate, short, curved, subcylindrical, white, with white mycelial patch at the base of 
the stipe. Context very thin, $0.5 \mathrm{~mm}$ thick, whitish, inmutable when exposed. Odor and taste nondistinctive. Spore print whitish.

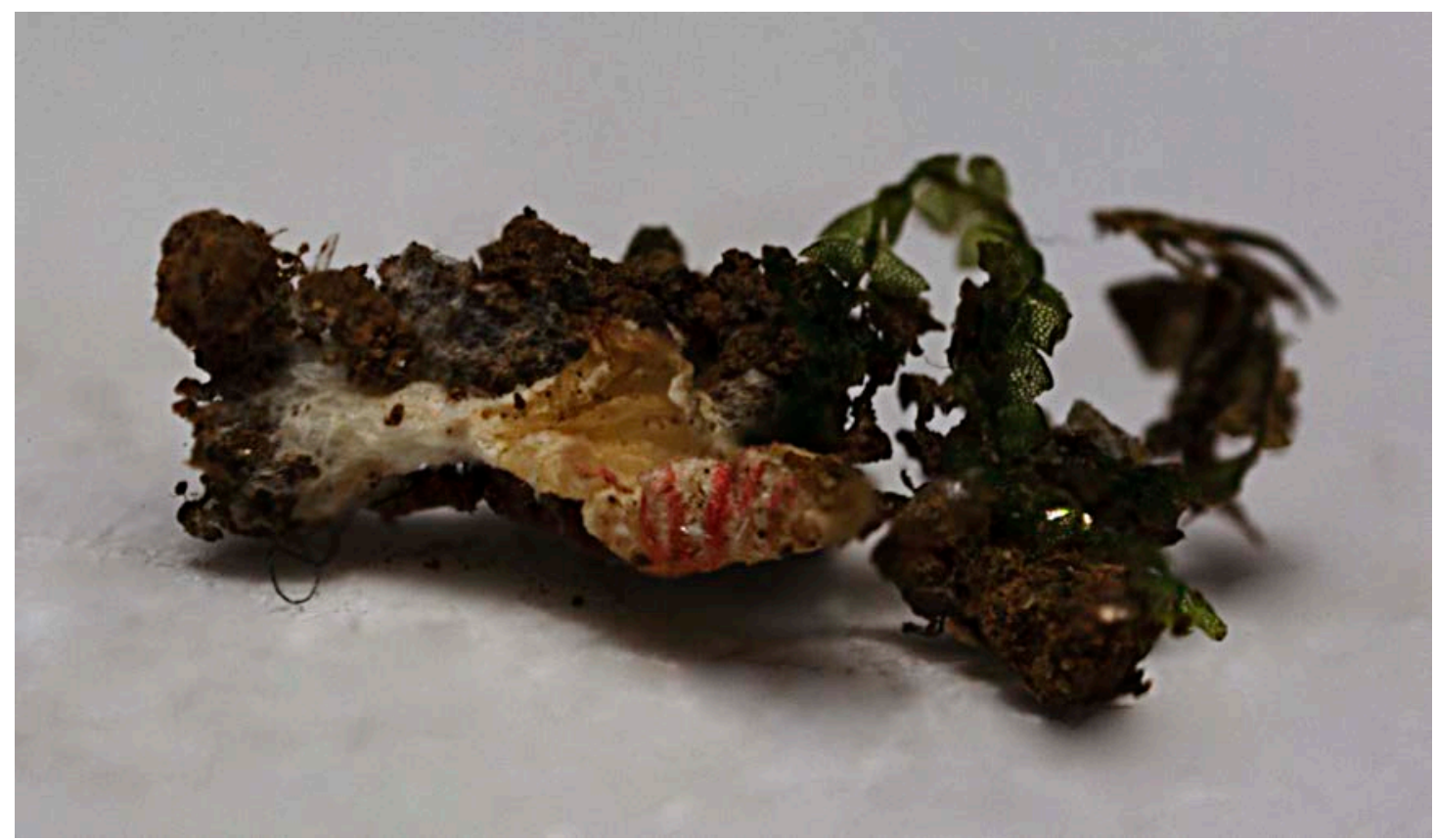

Fig. 1 - Arrhenia pontevedrana (LOU-Fungi 19669, holotype).

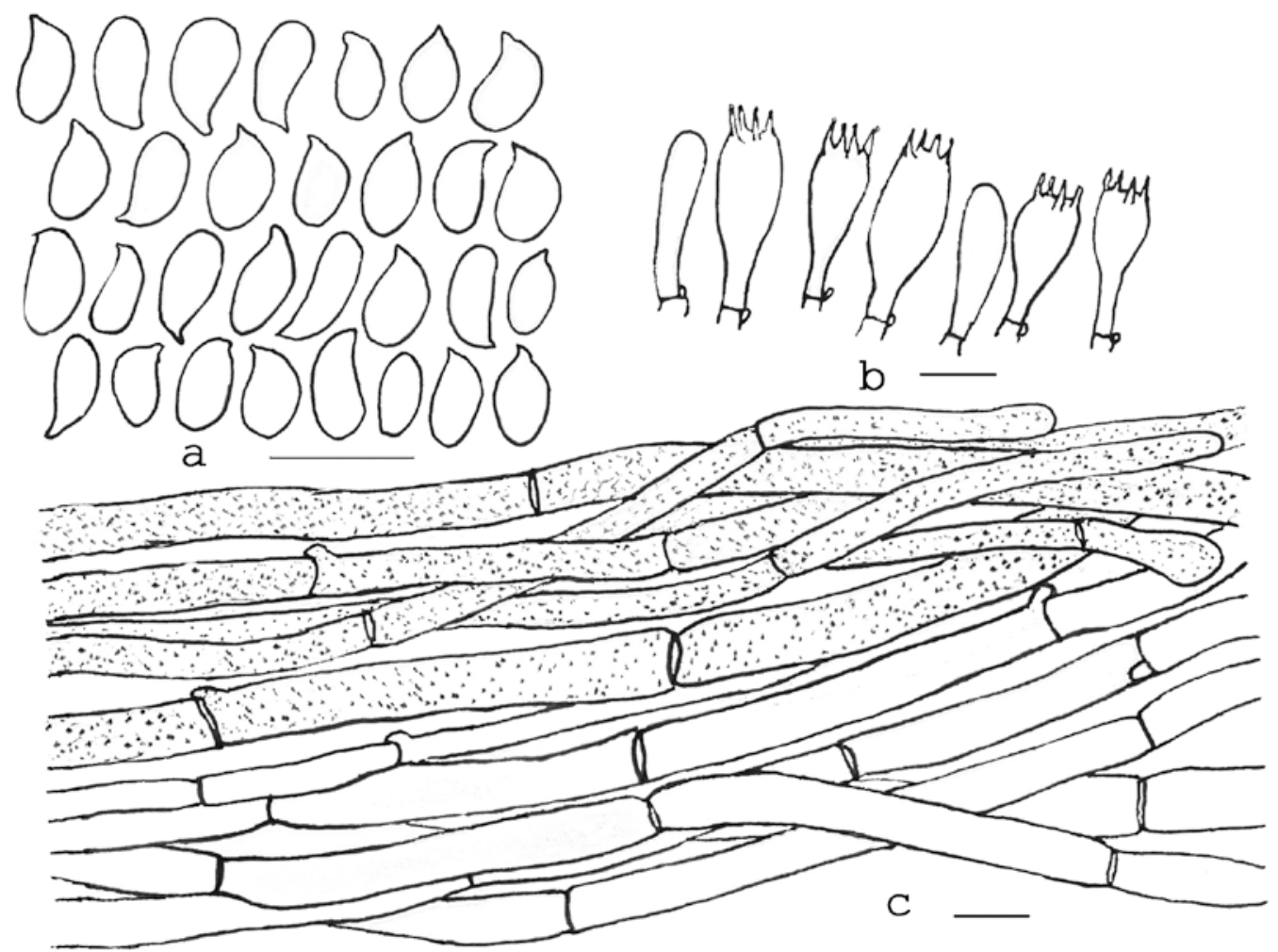

Fig. 2 - Arrhenia pontevedrana (LOU-Fungi 19669, holotype). a Basidiospores. b Basidia and basidioles. c Pileipellis. Scale bar $=10 \mu \mathrm{m}$.

Basidiospores (5) 5.5-6.5 (7) × (2.8) 3-3.5 (4) $\mu \mathrm{m}, \mathrm{Q}=1.55-2, \mathrm{Qm}=1.75(\mathrm{n}=30)$, ellipsoidal to oblong, smooth, hyaline, non-amyloid, thin-walled. Basidia 15-21.5 × 5-7.5 $\mu \mathrm{m}$, clavate, 4- 
spored, clamped, sterigmata up to $6 \mu \mathrm{m}$ long. Basidioles clavate. Pleurocystidia and cheilocystidia absent, lamellar edge fertile. Pileipellis a cutis of subparallel to interwoven hyphae, 2.5-9 $\mu \mathrm{m}$ diam., sometimes with restricted septa, smooth to usually with parietal and moderately encrusting ochre-gray to brown pigment, irregularly distributed on walls; terminal cells obtuse, subcylindrical or clavate. Pileus and lamellar trama interwoven, hyphae 2-10 $\mu \mathrm{m}$ diam, smooth, hyaline or with greyish or ochre-brown contents, inamyloid, non-gelatinous, thin-walled. Clamps present in all tissues.

Known distribution - So far only known from the type locality in Pontevedra (Spain).

Material examined - Spain, Pontevedra: Pontevedra, Lourizán, 29TNG2795, 40 m, among short mosses on granitic soil, on the edge of a trail under mixed forest (Picea abies, Eucalyptus globulus and Castanea x coudercii), 5 December 2012, J.B. Blanco-Dios (LOU-Fungi 19669, holotype).

Notes - This new species can be distinguished easily from other non-omphalinoid Arrhenia by the following combination of features: small, pleurotoid basidiomes with pink-red bands covering the pileus and small basidiospores (5.5-6.5 $\times 3-3.5 \mu \mathrm{m}, \mathrm{Q}=1.55-2)$. Among the morphologically similar species, the closest taxa is Arrhenia roseola (Quél.) Senn-Irlet.This related species differs specially from $A$. pontevedrana in having different pileus, lamellae and stipes color (from pale pink to deep pink), pelargonium smell and obovoid bigger basidiospores (7.3-10 × 4.6$7 \mu \mathrm{m}$ ) (Senn-Irlet 1986, Hertzog 2005, Corriol 2016). In conclusion, we do not found similar species with its unique combination of macroscopic and microscopic characteristics. We have found two basidiomata of this species in 2012 but we have made numerous visits to this place for the subsequent six years than they have been unsuccessful.

\section{Arrhenia subglobisemen Corriol, Bull. trimest. Féd. Mycol. Dauphiné-Savoie 222:14.2016}

Figs 3-4

Basidiomata pleurotoid or, exceptionally, spatulate. Pileus $8.5-27 \mathrm{~mm}$ broad, involute when young, flabellate, dorsally or laterally attached, margin lobate and/or undulate, furfuraceous, hygrophanous, translucent, gray to gray-ochraceous when moist or drying. Lamellae well developed, thin, moderately spaced, decurrent to adnate, entirely furfuraceous, gray, edge concolourous, even, obtuse; lamellulae abundant, irregular. Stipe 5-8 × 2.5-7 mm, attached laterally from pileus to the substrate (mosses), short, curved, subcylindrical, concolorous with hymenophore. White mycelium at the base. Context thin, ochre-gray, inmutable when exposed. Smell strong of raw fish with shades of fresh flour.Taste of paint and rafanoid, which persists for hours in the mouth. Spore print whitish.

Basidiospores (4) 4.5-6.5 (7.5) × (3.5) 4-6 $\mu \mathrm{m}, \mathrm{Q}=1.1-1.3, \mathrm{Qm}=1.16(\mathrm{n}=30)$, subglobose to broadly ellipsoidal, smooth, hyaline, non-amyloid, thin-walled. Basidia 15-26 $\times$ 5-9.5 $\mu \mathrm{m}$, subcylindrical to clavate, 4-spored, clamped, sterigmata usually curved or sometimes straight and up to $5 \mu \mathrm{m}$ long. Basidioles clavate. Pleurocystidia and cheilocystidia absent, lamellar edge fertile. Pileipellis a cutis of subparallel to interwoven hyphae, 3-12 $\mu \mathrm{m}$ diam., sometimes with restricted septa, smooth to usually with parietal and moderately encrusting ochre-gray to brown pigment, irregularly distributed on walls; terminal cells obtuse, subcylindrical or clavate. Pileus and lamellar trama interwoven, hyphae 2.5-13 $\mu \mathrm{m}$ diam, smooth, hyaline or with greyish or ochre-brown contents, inamyloid, non-gelatinous, thin-walled. Clamps present in all tissues.

Material examined - Spain, Pontevedra: Pontevedra, Tomeza, San Cibrán, 29TNG3095, 130 $\mathrm{m}$, on several mosses species (Campylopus introflexus, Dicranum scoparium,Pleurozium schreberi) on granitic soil, under Cytisus striatus in mixed forest (Eucalyptus globulus and Pinus pinaster), 5 January 2018, J.B. Blanco-Dios (LOU-Fungi 20040, holotype); ibidem, 11 January 2018, J.B. Blanco-Dios (LOU-Fungi 20041).

Notes - Arrhenia subglobisemen is characterized by the presence of subglobose basidiospores and is found fixed on large mosses (Campylopus, Dicranum,Hylocomnium,Pleurozium).This rare species is reported in Europe from France (Favre 1939, Corriol 2016) and Switzerland (Favre 1960) and has been cited out of Europe from Canada (Pomerleau 1980,Voitk 2017) and United States 
(Pomerleau 1980).We extend the range of this taxon in Europe from the French Pyrenees (Corriol 2016) to the northwest of the Iberian Peninsula.

We have noted the presence of smell strong of raw fish with shades of fresh flour, unusual within the genus Arrhenia (could it be a sign of infection of the basidiomata?) instead of observing the smell of pelargonium mentioned by other authors (Kühner \& Lamoure 1972, Elborne 2008, Corriol 2016).

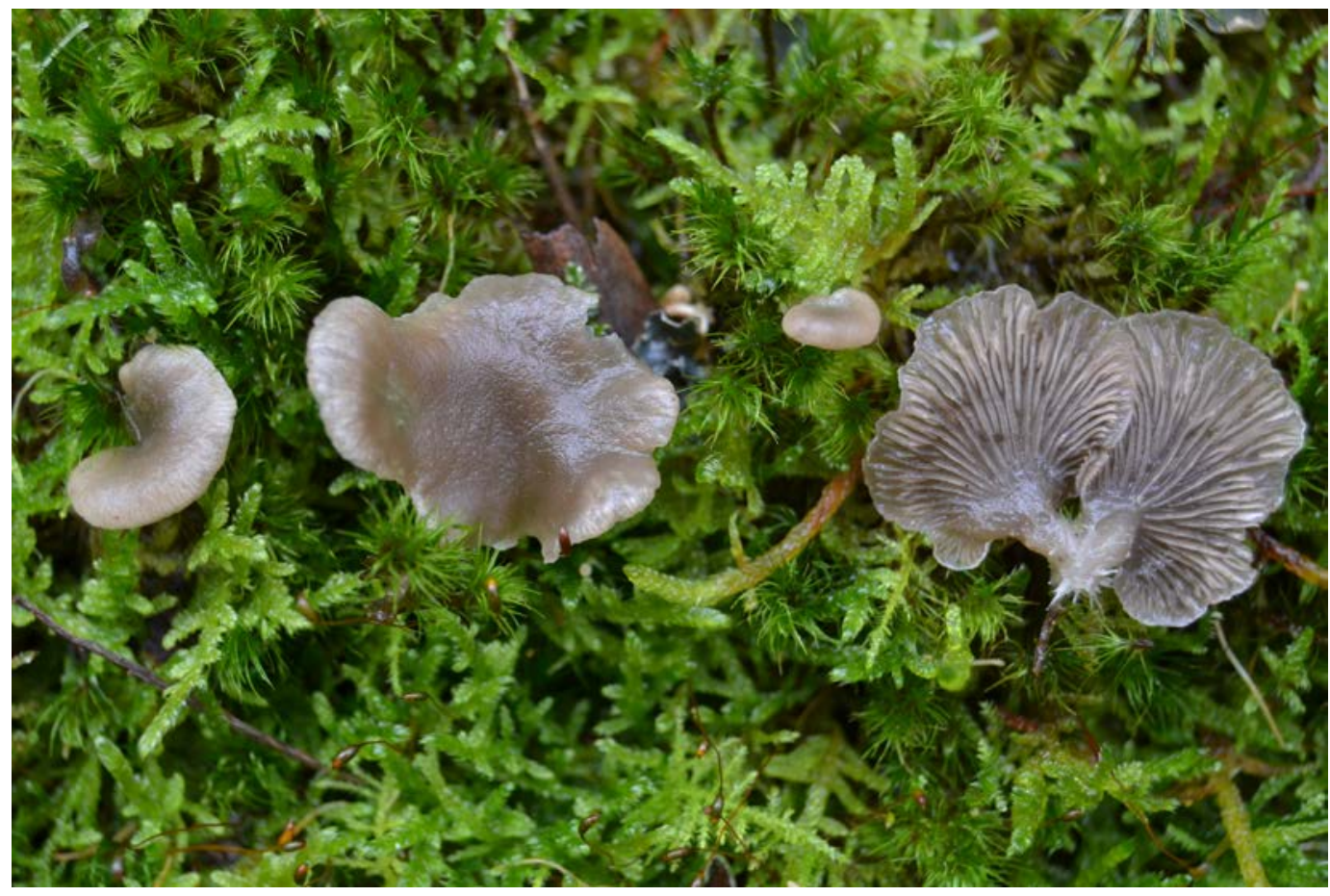

Fig. 3 - Arrhenia subglobisemen (LOU-Fungi 20040).
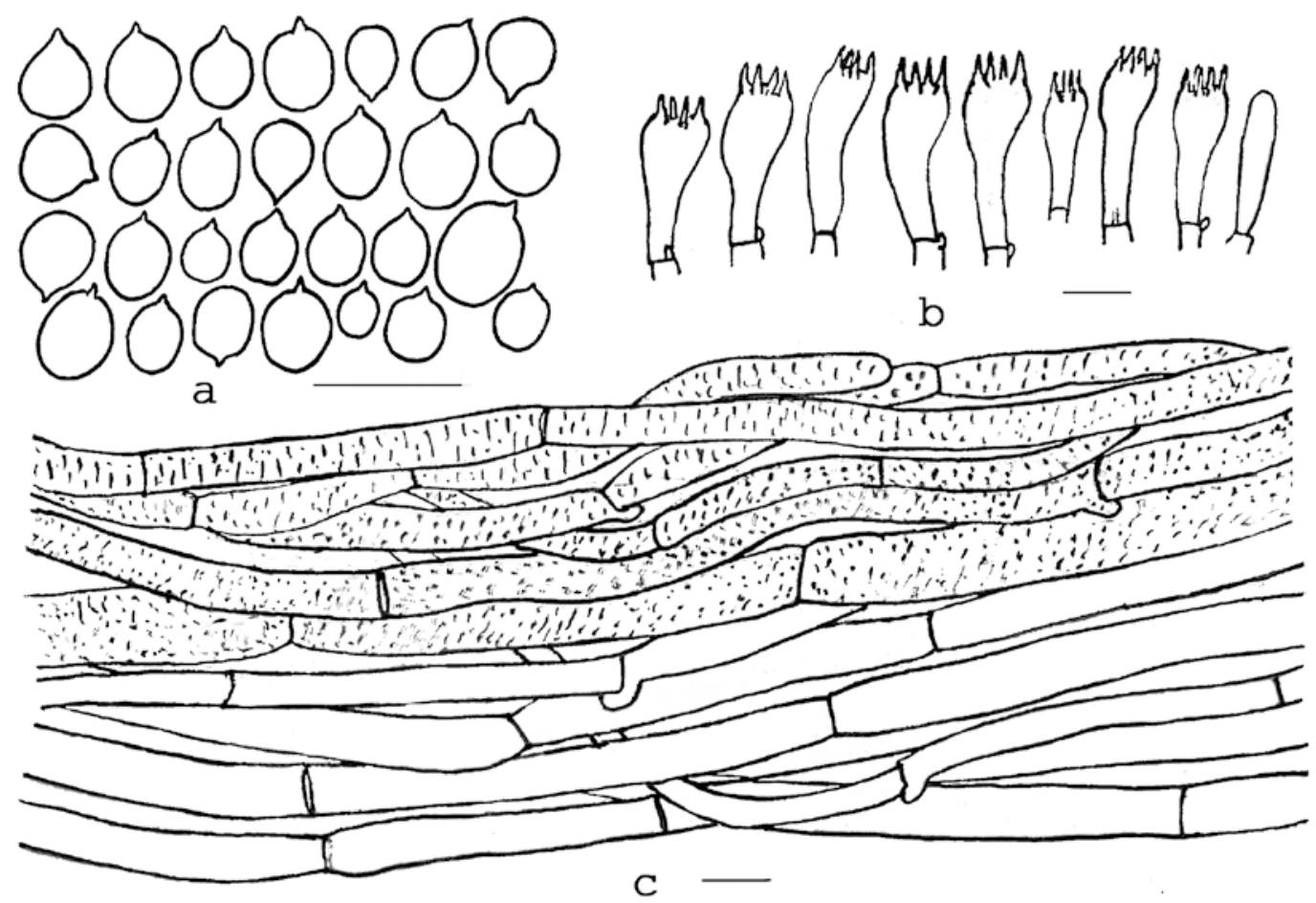

Fig. 4 - Arrhenia subglobisemen (LOU-Fungi 20040). a Basidiospores. b Basidia and basidioles. c Pileipellis. Scale bar $=10 \mu \mathrm{m}$. 
Finally, we proposed the following new combination:

Arrhenia kuhnerii Blanco-Dios, nom. nov.

Mycobank number: MB 823938

Basonym: Pleurotellus acerosus var. tenellus Kühner, in Kühner \& Romagnesi, Bull. Soc. nat. Oyonnax 8: 76.1954. Non Arrhenia tenella (Lam. \& DC.) Fr., Summa veg. Scand., Sectio Post. (Stockholm): 462. 1849

Etymology - kuhnerii: dedicated to Dr. R. Kühner.

Notes - As they propose Barrasa \& Rico (2003) we consider that the micromorphological (lacrimoid basidiospores (10-14.5 × 5-8 $\mu \mathrm{m}, \mathrm{Q}=1.8-2)$, and, generally, bisporic basidia) and ecological characters (tendency to grow in wetlands, on rotten grass or moss debris) that distinguish this variety can be used to recognize this taxon at the species level.

Key to the non-omphalinoid species of Arrhenia in the Iberian Peninsula (based in Barrasa \& Rico (2003))

1. Species with clamp connections

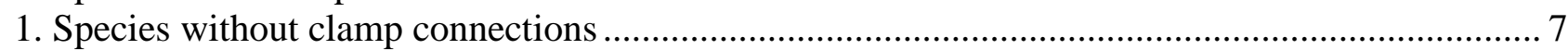

2. Basidiomata pleurotoid, with short or absent stipe, lamellae well developed................................ 3

2. Basidiomata pleurotoid, stipe present or absent, lamellae forked, reduced to vein-like or rib-like wrinkles.Basidiospores broadly ellipsoidal to ellipsoidal,Q=1.3-1.7

3. Basidiospores subgloboses to broadly ellipsoidal, $\mathrm{Q}=1.1-1.3$

A. subglobisemen Corriol

3. Basidiospores broadly ellipsoidal to elongate, $\mathrm{Q}=1.5-2$

4. Basidia bisporic, occasionally mono-, tri- or tetrasporic. Basidiospores $10-14.5 \times 5-8 \mu \mathrm{m}$, $\mathrm{Q}=1.8-2$.

A. kuhnerii Blanco-Dios

4. Basidia tetrasporic

5. Pileus coated with pink-red bands. Basidiospores 5.5-6.5 × 3-3.5 $\mu \mathrm{m}, \mathrm{Q}=1.55-2$

A. pontevedrana Blanco-Dios

5. Pileus whitish, gray, gray-brown or ochre-brown. Basidiospores 7.5-10 × 5-6.5 $\mu \mathrm{m}, \mathrm{Q}=1.5-1.7$..

A. acerosa (Fr.) Kühner

6. Basidiomata dorsally or laterally attached, stipe absent.Basidiospores broadly ellipsoidal, Q=1.3.

On mosses in peaty sites ....................................... A. lobata (Pers.) Kühner \& Lamoure ex Redhead

6. Basidiomata stipitate, hymenophore delimited from a solid stipe by a sterile lateral margin.

Basidiospores ellipsoidal to slightly elongate, $\mathrm{Q}=1.4-1.7$. On soil among mosses

A. auriscalpium (Fr.) Fr.

7. Basidiomata cupulate, dorsally attached, stipe absent, hymenophore delimited by a sterile margin. Spores ellipsoidal to oval, $\mathrm{Q}=1.6$. Usually on pleurocarpous mosses.....

A. retiruga (Bull.) Redhead

7. Basidiomata pleurotoid, with a lateral and well-developed stipe continuous with the hymenophore. Spores elongate or lacrimiform, $\mathrm{Q}=1.7$. Usually on acrocarpous mosses

A. spathulata (Fr.) Redhead

\section{Acknowledgements}

The author is grateful to Amancio Castro for providing the photograph of Arrhenia pontevedrana and technical assistance. Helena Velayos and José Rodríguez Vázquez are gratefully acknowledged for kindly sending relevant literature. Two anonymous reviewers are thanked for helpful suggestions. We express the most sincere thanks to the director and members of the Centro de Investigación Forestal de Lourizán (Consellería do Medio Rural, Xunta de Galicia) for conserving the herbarium LOU-Fungi. 


\section{References}

Barrasa JM, Rico VJ. 2003 - The non-omphalinoid species of Arrhenia in the Iberian Peninsula. Mycologia 95(4), 700-713.

Barrasa JM, Rico VJ, Villareal M. 2003 - Arrhenia eburnea, sp. nov. from Spain. Mycotaxon 88, 113-118.

Corriol G. 2016 - Arrhenia subglobisemen, un nouveau nom pour Agaricus tremulus sensu Persoon, Fries. Bulletin Trimestrel Féderation Mycologique Dauphiné-Savoie 222, 5-20.

Elborne SA. 2008 - Arrhenia Fr. Funga Nordica. 1st ed. Eds. H. Knudsen, J. Vesterholt. Copenhagen: Nordsvamp, pp. 226-234.

Favre J. 1939 - Champignons rares ou peu connus des hauts-marais jurassiens. Bulletin de la Société Mycologique de France 55, 196-219.

Favre J. 1960 - Catalogue descriptif des champignons supérieurs de la zone subalpine du Parc National Suisse. Ergebnisse der Wissenschaftlichen Untersuchungen des Scheizerischen Nationalparks 6, 323-610 + 8 pl.

Hertzog P. 2005 - Notes sur quelques espèces pleurotoïdes. Bulletin Societé Mycologique du Haut Rhin 22, 18-20

Index Fungorum 2019 - http://www.indexfungorum.org (accessed 20 July 2019).

Kühner R, Lamoure D. 1972 - Agaricales de la zone alpine. Pleurotacées. Le Botaniste 55, 7-37.

Moncalvo JM, Lutzoni FM, Rehner SA, Johnson J, Vilgalys R. 2000 - Phylogenetic relationships of agaric fungi based on nuclear large subunit ribosomal DNA sequences. Systematic Biology 49, 278-305.

Moncalvo JM, Vilgalys R, Redhead SA, Johnson JE et al. 2002 - One hundred and seventeen clades of euagarics. Molecular Phylogenetics Evolution 23, 357-400.

Norvell LL, Redhead SA, Ammirati JF. 1994 - Omphalina sensu lato in North America 1-2. 1: Omphalina wynniae and the genus Chrysomphalina. 2: Omphalina sensu Bigelow. Mycotaxon 50, 379-407.

Pomerleau R. 1980 - Flore des champignons au Québec.Montréal, La Presse.

Redhead SA. 1984 - Arrhenia and Rimbachia, expanded generic concepts, and a reevaluation of Leptoglossum with emphasis on musicolous North American taxa. Canadian Journal of Botany 62(5), 865-892.

Redhead SA, Lutzoni F, Moncalvo JM, Vilgalys R. 2002 - Phylogeny of agarics: partial systematics solutions for core omphaloid genera in the Agaricales (euagarics). Mycotaxon 83, 19-57.

Senn-Irlet B. 1986 - Ökologie, Soziologie und Taxonomie alpiner Makromyzeten (Agaricales, Basidiomycetes) der Schweizer Alpen. Dissertation Universität Bern.

Voitk A. 2017 - Arrhenia subglobisemen. Newsletter of Foray Newfoundland and Labrador.Vol VIII (5), 19. 